\title{
Assessment of Morphological and Morphometrical Variations of Sacral Hiatus in Dry Human Sacrum in Ethiopia
}

This article was published in the following Dove Press journal: Local and Regional Anesthesia

\author{
Zerihun Abera' \\ Amanuel Girma $\mathbb{D D}^{2}$ \\ Assegedech Bekele ${ }^{2}$ \\ Mohammed Oumer $\mathbb{( D}^{2,3}$ \\ 'Department of Biomedical Sciences, \\ School of Medicine, College of Medicine \\ and Health Sciences, Arsi University, Arsi, \\ Oromia, Ethiopia; ${ }^{2}$ Department of \\ Human Anatomy, School of Medicine, \\ College of Medicine and Health Sciences, \\ University of Gondar, Gondar, Amhara, \\ Ethiopia; ${ }^{3}$ Department of Epidemiology, \\ Institute of Public Health, College of \\ Medicine and Health Sciences, University \\ of Gondar, Gondar, Amhara, Ethiopia
}

Background: The sacral hiatus is an opening present at the lower end of the sacral canal. The anatomy of the sacral hiatus and its variations are clinically important during administration of caudal epidural block (CEB) in obstetrics and gynecology, orthopedic, urology and general surgical practices. The success and reliability of CEB depends upon the sound knowledge of anatomical variations of the sacral hiatus.

Objective: The aim of this study was to assess the morphological and morphometric variation of the sacral hiatus in dry human sacrum.

Methods: An institution-based observational cross-sectional study design was conducted to assess morphological and morphometric variations of the sacral hiatus in 61 dry human sacrum specimens at the anatomy departments of Gondar, Addis Ababa, Hawassa and Jimma universities and Hayat and Korea Medical Colleges in Addis Ababa. Descriptive analysis was applied to analyze the data.

Results: The most commonly recorded shape of the sacral hiatus is inverted-V (41\%) followed by inverted-U (37.7\%). The least common was complete bifida (1.6\%). The apex of the sacral hiatus is mostly seen at the level of the 4th sacral vertebra $(60.7 \%)$, while the base is commonly located at the level of the 5 th sacral vertebra (78.7\%). The mean length of the sacral hiatus is $22.67 \pm 11.84 \mathrm{~mm}$. The mean transverse width and mean anteroposterior diameter of the sacral hiatus at the apex are $13.14 \mathrm{~mm} \pm 2.85 \mathrm{~mm}$ and $5.57 \mathrm{~mm} \pm 1.53 \mathrm{~mm}$, respectively.

Conclusion: The sacral hiatus has anatomical variations. These variations should be kept in mind during administration of caudal epidural anesthesia and analgesia.

Keywords: assessment, sacrum, sacral hiatus, variations, Ethiopia

\section{Background}

The sacrum is a large triangular bone formed by the fusion of five sacral vertebrae in adults. ${ }^{1-6}$ The sacrum forms the postero-superior wall of the pelvic cavity, wedged between the two innominate bones. ${ }^{7-9}$ It has a blunted caudal apex which articulates with the coccyx and a superior wide base which articulates with the fifth lumbar vertebra at the lumbosacral angle. In addition the sacrum presents pelvic, dorsal and lateral surfaces and a sacral canal. The opening at the caudal end of the sacral canal is known as the sacral hiatus $(\mathrm{SH}) .{ }^{10,11}$ It is formed due to the failure of fusion of laminae of the fifth (occasionally fourth) sacral vertebra. It is located inferior to the fourth (or third) fused sacral spines or the lower end of the median sacral crest. $^{10-12}$
Correspondence: Amanuel Girma Tel +251913554235

Email amanuelgirma.w@gmail.com

Local and Regional Anesthesia 2021:14 25-32 
The sacral hiatus (SH), which is roughly triangular in shape, contains the fifth sacral nerve, coccygeal nerve roots, filum terminale externum and fibro-fatty tissue. For a successful caudal epidural block (CEB), knowledge of the anatomy of the sacral hiatus and its variations is important. ${ }^{13}$

Anatomical variations occur frequently, making the sacrum the most variable portion of the spine. Developmental malformations occur ranging from variations in the sacral hiatus to caudal agenesis. ${ }^{14}$ The sacral hiatus shows variations during development. Non-fusion of laminae of the 4th or the upper vertebrae results in an elongated sacral hiatus. Non-fusion of all the sacral vertebrae results in sacral spina bifida. This leads to decreased surface area for the attachment of extensor muscle at the back, which may be a cause of backache. ${ }^{7}$

Considerable variability is seen in the anatomy of the sacral hiatus, which may be closed, asymmetrically open or wide open. As age advances, the overlying ligaments and the cornua thicken. Consequently, identification of hiatus margins becomes challenging. In addition to this, anatomic variations in size, shape and orientation of the sacral hiatus increase the problems in caudal anesthesia. ${ }^{15,16}$

For a successful CEB intervention, a fundamental knowledge of the anatomy of the sacral hiatus is a prerequisite. ${ }^{13}$ However, the considerable anatomical variations of the SH may make its identification difficult. ${ }^{17}$ A sacral approach to the epidural space is used for giving analgesia and anaesthesia for a variety of operations. Caudal epidural block (CEB) has been widely used for the treatment of lumbar spinal disorders and also for the management of chronic back pain. ${ }^{18}$ Caudal epidural block involves injection of a drug into the epidural space through the sacral hiatus to provide analgesia and anesthesia in various clinical settings. ${ }^{19}$ Caudal analgesia is used during surgical procedures in urology, proctology, general surgery, obstetrics and gynecology and orthopedics. Anesthetic agents are injected through the sacral hiatus in caudal epidural anesthesia to act on the sacral and coccygeal nerves and are often employed to relax the perineal musculature for painless childbirth. ${ }^{17}$

The reliability and success of caudal epidural anesthesia depends upon anatomical variations of the sacral hiatus as observed by various authors. Therefore, the aim of this study is to discover the anatomical variations of the sacral hiatus, investigating the morphometry and morphology of the sacrum in Ethiopia.

\section{Methods and Materials}

An institution-based descriptive cross-sectional study design was applied. A total of 61 dry human sacral bones held at the Department of Anatomy in Gondar, Jimma, Addis Ababa, Hawassa Universities, Hayat and Korea Medical Colleges in Addis Ababa were used within this study. The bones, which were of undetermined age and gender, were subjected to morphometric study. The analysis was carried out in two parts:

\section{Part I: Non-Metric Analysis}

1. The shape of the sacral hiatus was classified as inverted- $\mathrm{V}$ shape, inverted- $\mathrm{U}$ shape, dumb-bell shape, irregular shape, bifida shape and complete bifida shape.

2. Level of the apex of the sacral hiatus was evaluated in relation to the vertebra level as $\mathrm{S} 1, \mathrm{~S} 3, \mathrm{~S} 4$ and S5.

3. Level of the base of the sacral hiatus was evaluated in relation to the sacral and the coccygeal vertebra as S5, Co1.

\section{Part II: Metric Analysis}

1. Length of sacral hiatus: The distance from the apex to the midpoint of the base of the SH.

2. Transverse width of sacral hiatus (intercornual distance): The distance between the inner surface of the inferior limit of the sacral cornua.

3. Antero-posterior diameter of sacral hiatus: Anteroposterior depth at the apex of the SH.

The parameters were measured twice by the same author using caliper, divider and steel measuring tape. Observations were substantiated with photographs. Damaged, mutilated and deformed sacra were excluded. Descriptive analysis was applied to analyze the data.

\section{Ethical Approval and Consent}

The study protocol was approved by the ethical review committee of College of Medicine and Health Sciences, University of Gondar.

\section{Results}

\section{Part I: Non-Metric Analysis}

1. The sacral hiatus of each specimen was classified according to shape. The shape was mainly inverted$\mathrm{V}(41 \%)$ or inverted-U (37.7\%), which is normal 
Table I Shape of the Sacral Hiatus

\begin{tabular}{|l|l|l|l|}
\hline \multicolumn{2}{|l|}{ Shapes } & Frequency & Percent \\
\hline Valid & Bifida & 2 & 3.3 \\
& Complete bifida & 1 & 1.6 \\
& Dumb-bell & 7 & 11.5 \\
& Inverted-U & 23 & 37.7 \\
& Inverted-V & 25 & 41.0 \\
& Irregular & 3 & 4.9 \\
& Total & 61 & 100.0 \\
\hline
\end{tabular}

type. Dumb-bell shape (11.5\%) with a nodular bony growth projecting medially from both margins, irregular shape $(4.9 \%)$ and bifid shape $(3.3 \%)$ were also observed. The dorsal wall of sacral canal was entirely incomplete in $1.6 \%$ of cases (Table 1) (Figure 1-6).

2. The level of the apex of the sacral hiatus varied from $\mathrm{S} 1$ to S5. It was as high as $\mathrm{S} 1$ in 3.3\%, as low as $\mathrm{S} 5$ in $9.8 \%$ and was most commonly located against S4 in $60.7 \%$ cases. In the remaining $26.2 \%$ of cases the apex was found at the S3 level (Table 2) (Figures 1, Figures 2, Figures 3Figures 4, Figures 5, Figures 6, Figures 7 and 8).

3. The level of the base of the sacral hiatus was commonly located at S5 (78.7\%). In $21.3 \%$ of

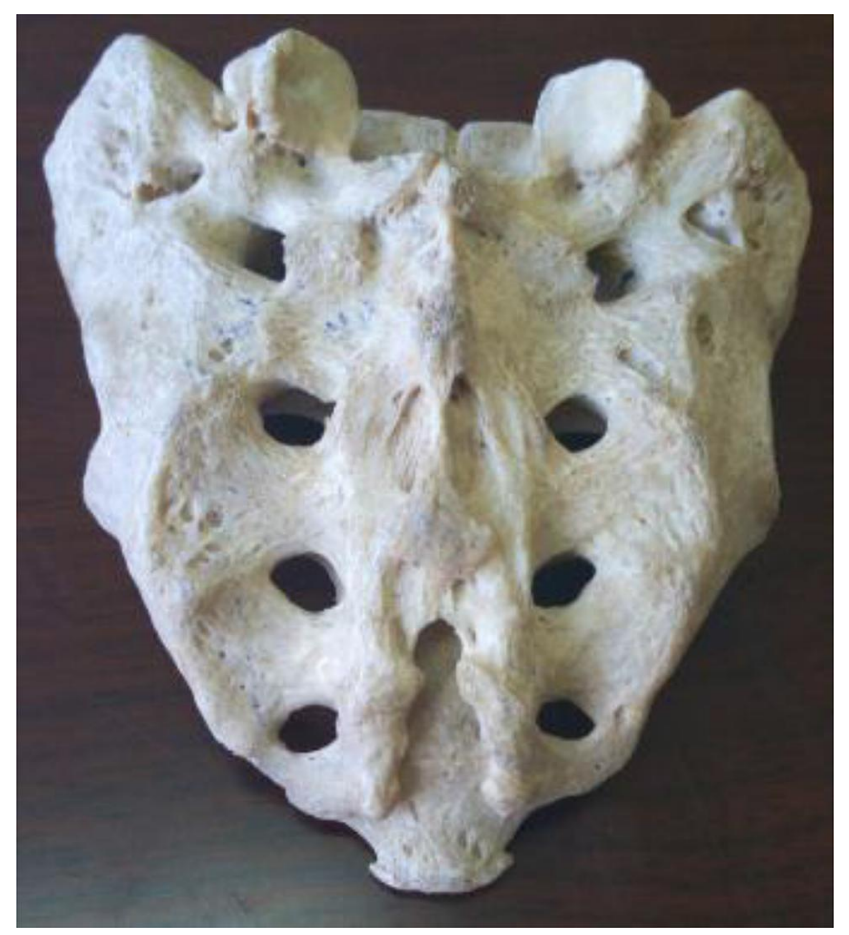

Figure I Schematic representation of dumb-bell shape of $\mathrm{SH}$.

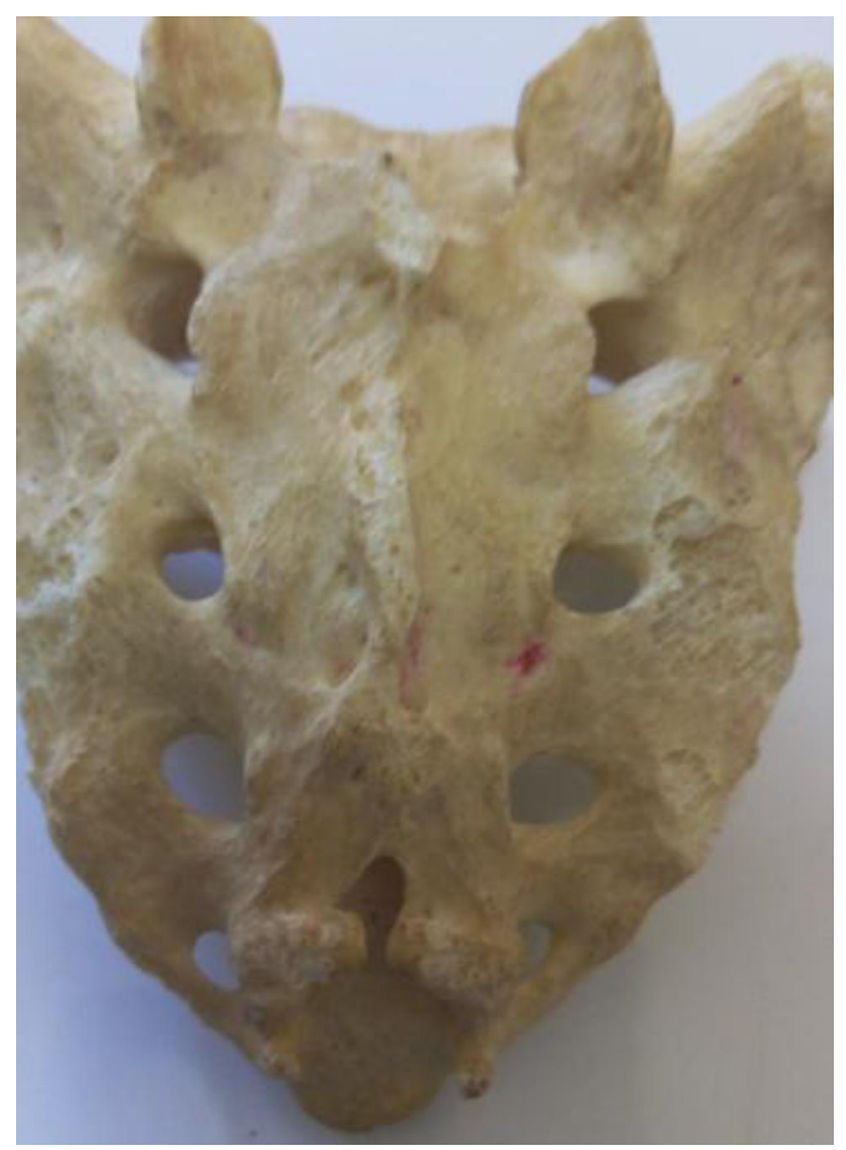

Figure 2 Schematic representation of bifida shape of $\mathrm{SH}$.

cases, the base was found at the first coccygeal level (Table 3) (Figures 9 and 10).

\section{Part II: Metric Analysis}

1. Length of the sacral hiatus varied from $6 \mathrm{~mm}$ to $80 \mathrm{~mm}$, with the arithmetic mean $22.67 \mathrm{~mm}$ and standard deviation $11.84 \mathrm{~mm}$. The proportion of sacrum specimens having a sacral hiatus length of $0-10 \mathrm{~mm}$ was $4.9 \%$, while $45.9 \%$ had a length of $11-20 \mathrm{~mm}$ and $34.4 \%$ of human sacra had a sacral hiatus length of $21-30 \mathrm{~mm} ; 14.7 \%$ of specimens had a sacral hiatus longer than $31 \mathrm{~mm}$ (Tables 4 and 5) (Figure 11).

2. Transverse width of the sacral hiatus (intercornual distance) varied from $9 \mathrm{~mm}$ to $21 \mathrm{~mm}$, with the arithmetic mean $13.14 \mathrm{~mm}$ and standard deviation $2.85 \mathrm{~mm}$. The majority of human sacra $(63.9 \%)$ had the transverse width in the range $11-15 \mathrm{~mm}, 19.7 \%$ had transverse width of $6-10 \mathrm{~mm}, 14.8 \%$ of the 


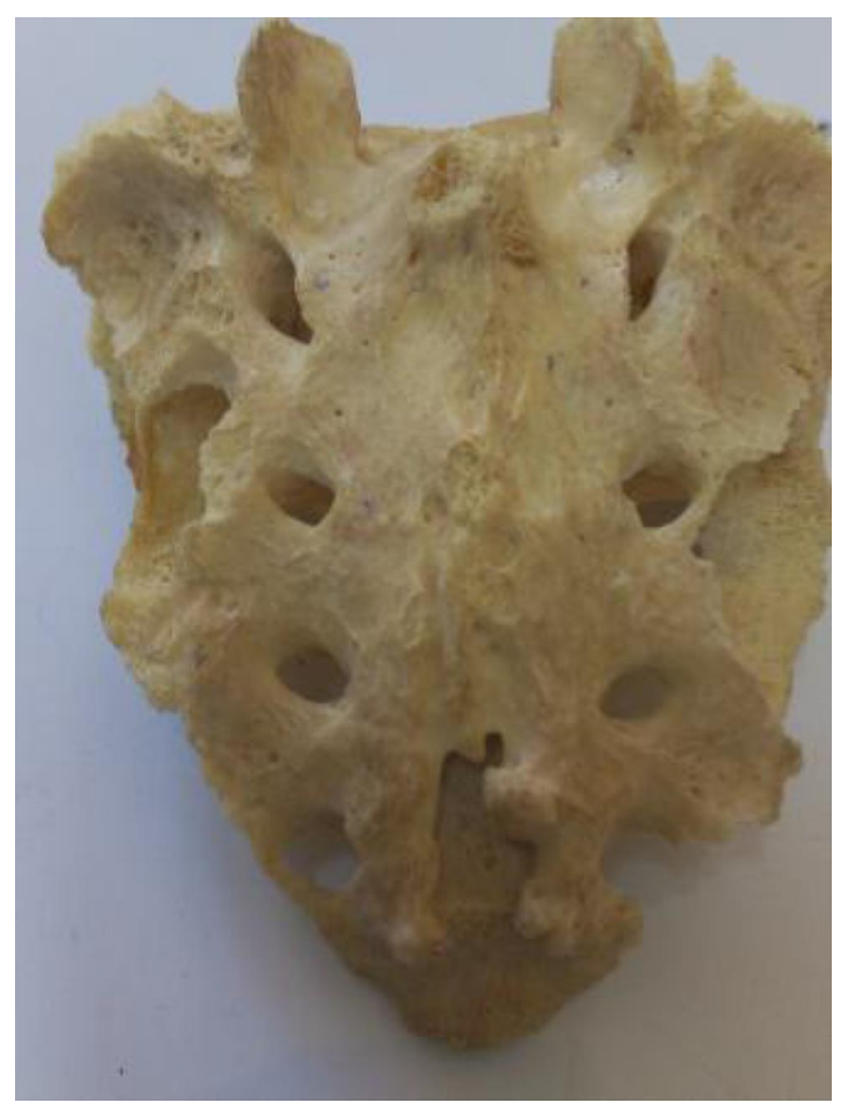

Figure 3 Schematic representation of irregular shape of $\mathrm{SH}$.

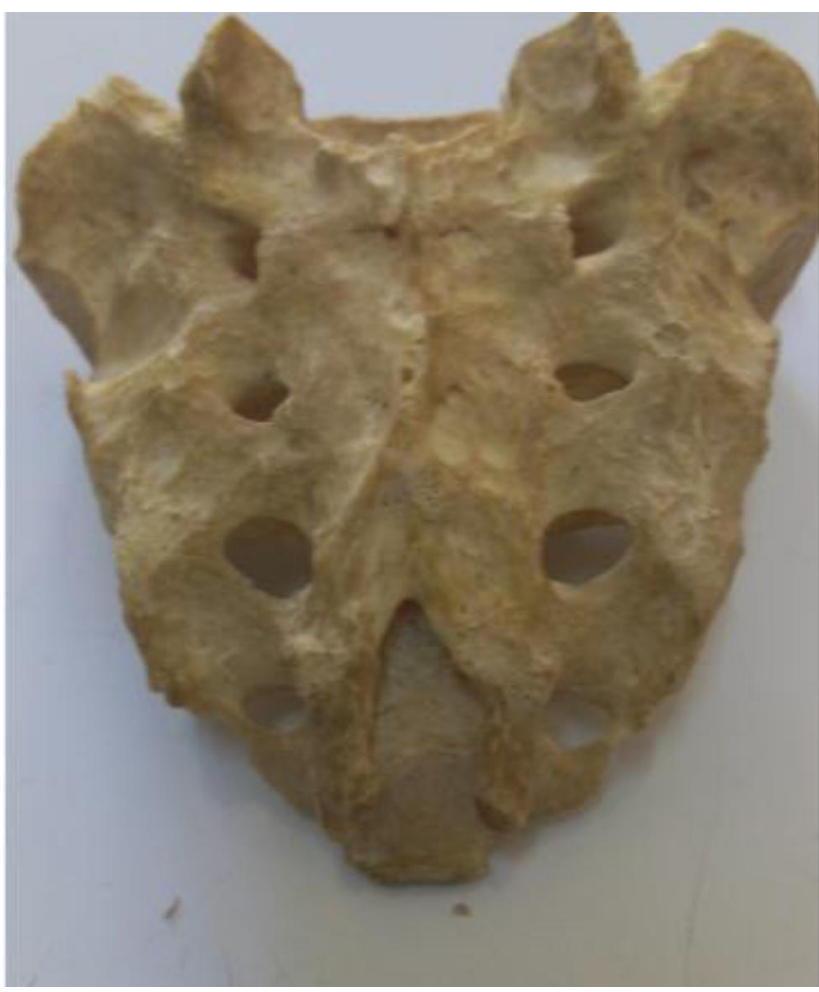

Figure 4 Schematic representation of inverted-V shape of $\mathrm{SH}$.

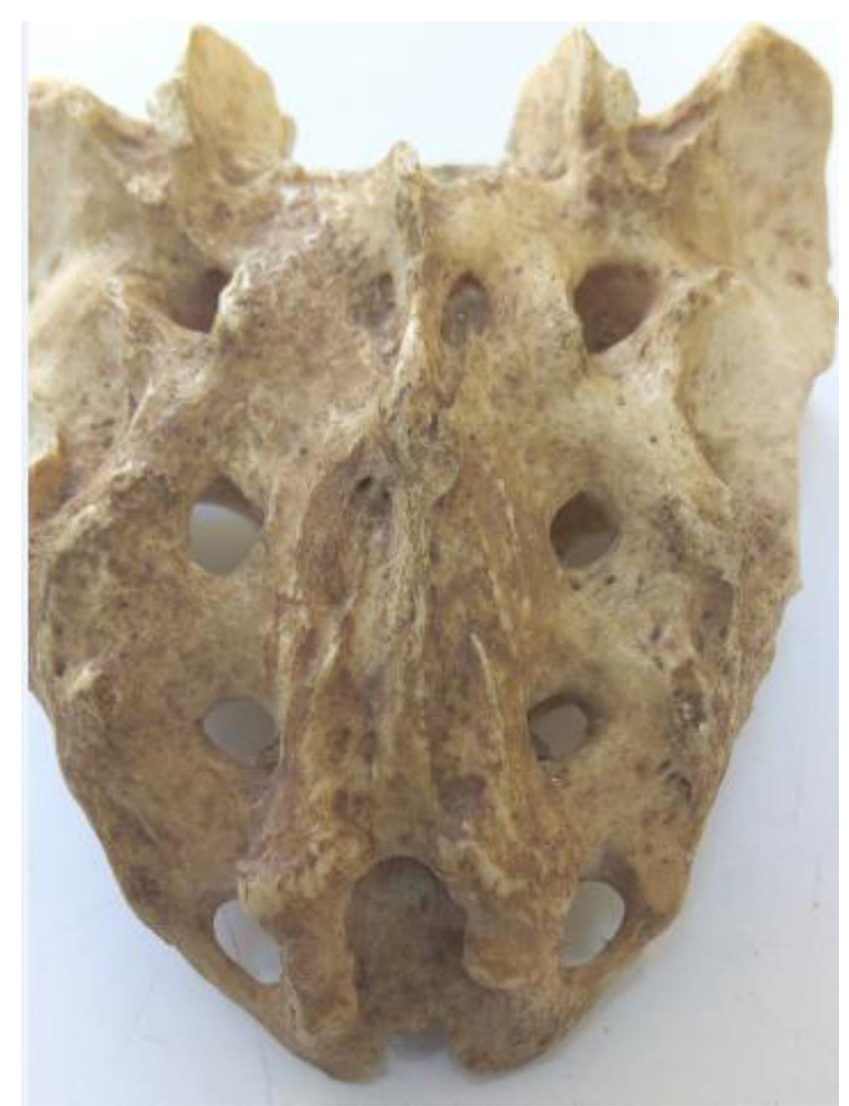

Figure $\mathbf{5}$ Schematic representation of inverted-U shape of $\mathrm{SH}$.

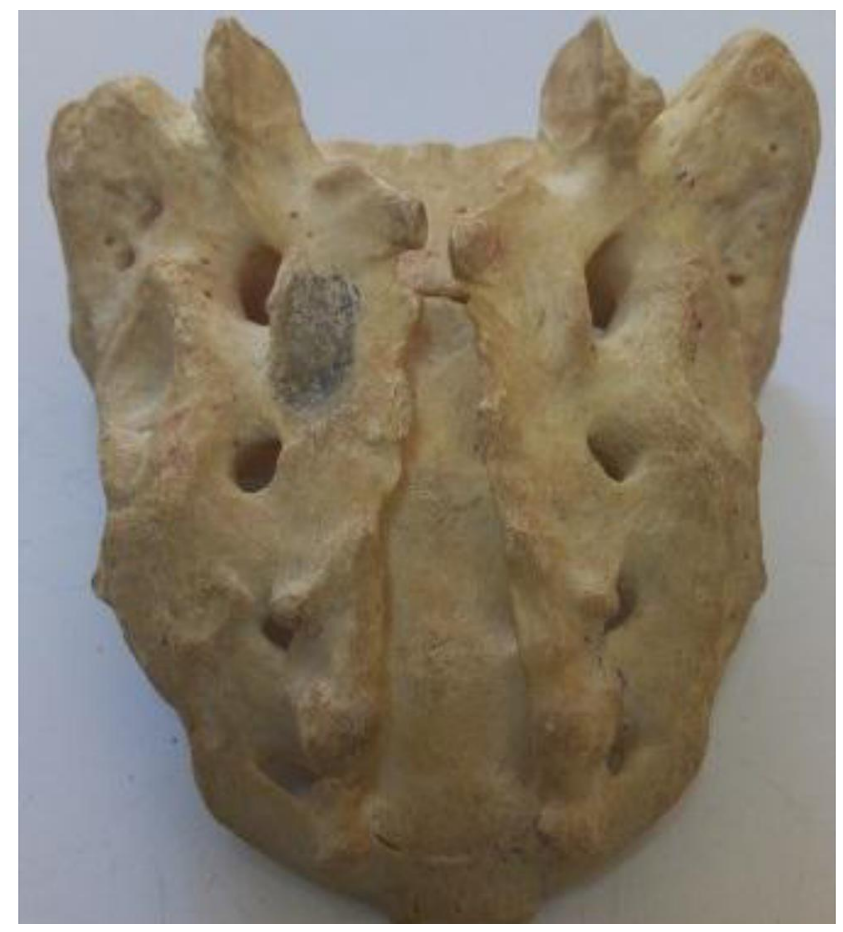

Figure 6 Schematic representation of complete bifida. 
Table 2 Level of Apex of SH with Respect to Level of Sacral Vertebra

\begin{tabular}{|l|l|l|}
\hline Level of Apex & Frequency & Percent \\
\hline SI & 2 & 3.3 \\
S3 & 16 & 26.2 \\
S4 & 37 & 60.7 \\
S5 & 6 & 9.8 \\
Total & 61 & 100.0 \\
\hline
\end{tabular}

human sacra had $16-20 \mathrm{~mm}$ and only $1.6 \%$ had the transverse width $>21 \mathrm{~mm}$ (Tables 4 and 5).

3. Antero-posterior diameter of sacral hiatus varied from $3 \mathrm{~mm}$ to $9 \mathrm{~mm}$, with the arithmetic mean $5.57 \mathrm{~mm}$ and standard deviation $1.53 \mathrm{~mm}$. The largest proportion (60.7\%) of human sacra had the AP diameter between 4 and $6 \mathrm{~mm}$, followed by $31.1 \%$ with AP diameter of 7-9 mm and only $8.2 \%$ associated with the AP diameter 0-3 mm (Tables 4 and 5).

\section{Discussion}

Caudal epidural block and caudal epidural anesthesia, which are accessed through the $\mathrm{SH}$, have a wide range of clinical applications. Successful CEB is possible with determining the anatomical structure of the $\mathrm{SH}^{20}$ The apex of $\mathrm{SH}$ location is also required for procedures such as colposcopy and trans-sacral endoscopy. ${ }^{21-23}$ However, because of anatomical

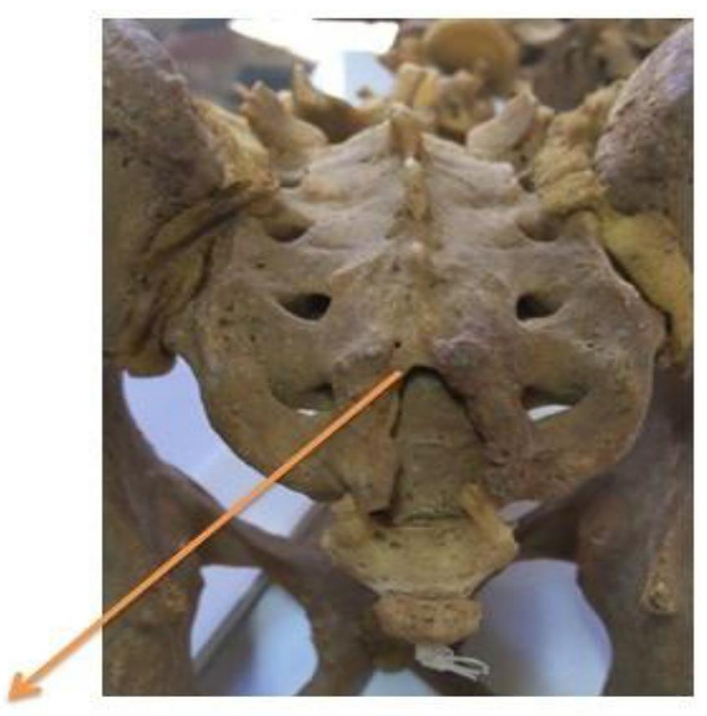

\section{Apex at $S 4$}

Figure 7 Schematic representation of level of apex at S4.

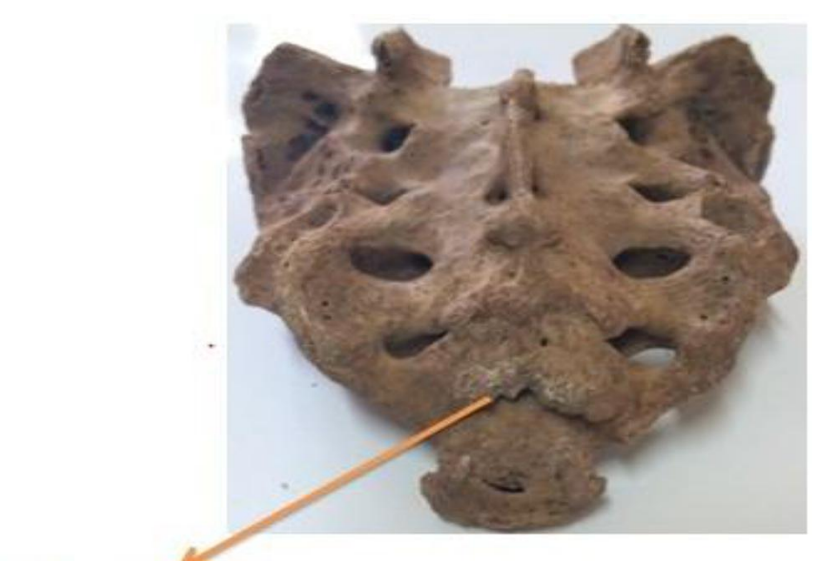

\section{Apex at $\mathbf{S} 5$}

Figure 8 Schematic representation of level of apex at S5.

variation of the $\mathrm{SH}$, a problem can be encountered during insertion of a needle in the sacral canal through the $\mathrm{SH}^{20}$ Locating the apex of the $\mathrm{SH}$ is also difficult because of its variation. ${ }^{14}$ Hence knowledge on anatomical structure of the $\mathrm{SH}$ is essential for successful clinical procedures.

The shape of the $\mathrm{SH}$ is one of the most important landmarks. ${ }^{15,16}$ Inverted-V (41\%) and inverted-U $(37.7 \%)$ were the most common types, somewhat similar to the results of the study by Ukoha et $\mathrm{al}^{24}$ who reported inverted-V (33.1\%) and inverted-U (24\%). This was contradictory to the observations by Bhattacharya et $\mathrm{al}^{25}$ who reported inverted-U (65\%) and inverted-V (23\%), and Doshi et $\mathrm{al}^{26}$ who reported inverted-V (14\%) and inverted-U (56\%). Inverted-V and inverted-U shapes provide enough space for inserting the needle into the sacral canal without obstacle and are considered as normal.

Thus, difficulties encountered in the SH may possibly be due to other SH types which accounted for $21.3 \%$. In our study, we found that $11.5 \%$ of SH were dumb-bell shaped, which is high compared with previous investigators who reported only $3 \%{ }^{27}$ and $9.3 \% .{ }^{24}$ Bifid sacral hiatus was seen in $3.3 \%$, which was similar to the report

Table 3 Level of Base of Sacral Hiatus with Respect to Level of Sacral Vertebra

\begin{tabular}{|l|l|l|}
\hline Level of Base & Frequency & Percent \\
\hline Col & 13 & 21.3 \\
S5 & 48 & 78.7 \\
Total & 61 & 100.0 \\
\hline
\end{tabular}




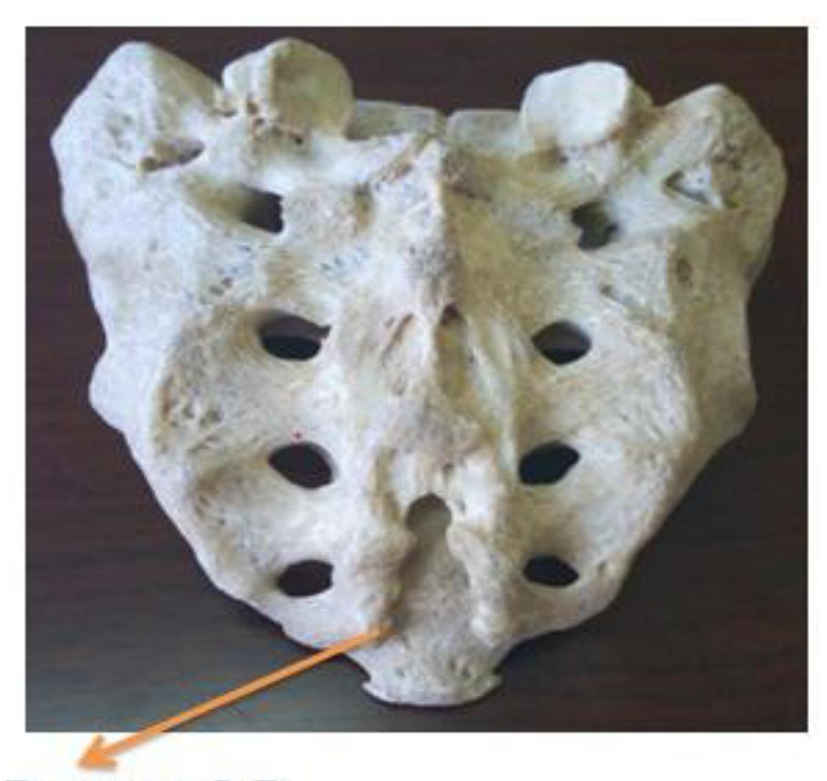

\section{Base at S 5}

Figure 9 Schematic representation of level of base at S5.

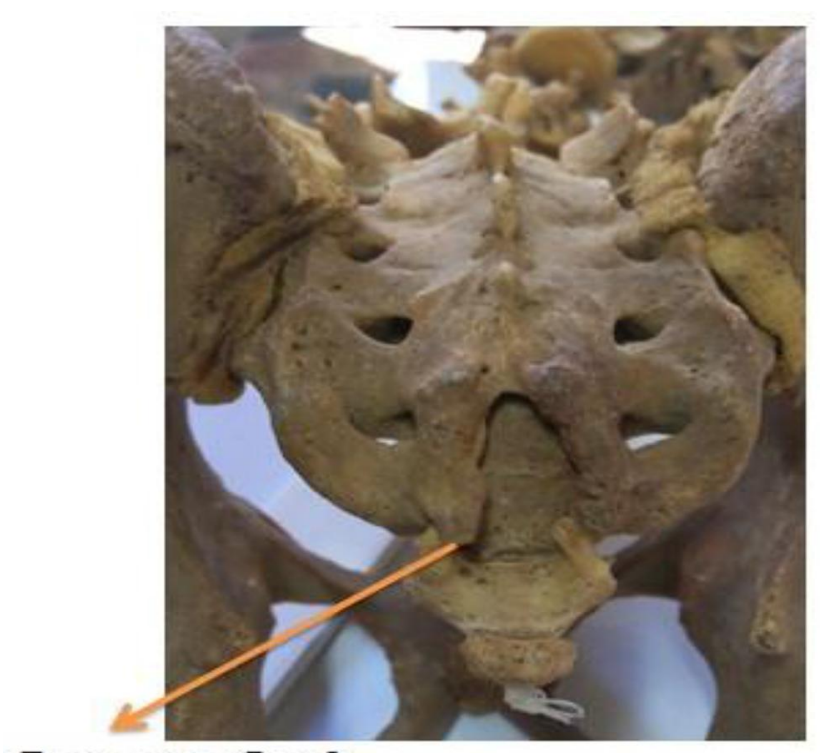

Base at Co 1

Figure 10 Schematic representation of level of base at Col.

by Malarvani et $\mathrm{al}^{27}(3 \%)$. Complete spina bifida was observed in $1.6 \%$, which is low when compared with observation by Malarvani et $\mathrm{al}^{27}(3 \%)$. Irregular shape was found in $4.9 \%$, with Malarvani et $\mathrm{al}^{27}$ and Desai et $\mathrm{al}^{26}$ reporting $14 \%$ and $16 \%$, respectively.

Knowledge of the apex of the $\mathrm{SH}$ is important to ensure safety of dura. The apex of $\mathrm{SH}$ location was most frequently reported at level of S4.
Bhattacharya et $\mathrm{al}^{25}$ and Ukoha et $\mathrm{al}^{24}$ reported $74 \%$ and $66.6 \%$, respectively. In our study it was $60.7 \%$. Apex of the SH located at S3 and above, accounting for $29.5 \%$ in our study, is not safe since it is close to the dura mater.

Base of the $\mathrm{SH}$ location is frequently reported at the level of the S5 vertebra. In the works of Malarvani et al, ${ }^{27}$ Desai et $\mathrm{al}^{26}$ and Ukoha et al, ${ }^{24}$ the prevalence was $54 \%$, $62 \%$ and $59.3 \%$, respectively. In this study, a base of the $\mathrm{SH}$ at coccyx level was found in $21.3 \%$ of specimens. In the works of Malarvani et $\mathrm{al}^{27}$ and Ukoha et $\mathrm{al}^{24}$ the figures were $1 \%$ and $14 \%$, respectively. In this study, the base was defined as S5 segment in $78.7 \%$ of specimens.

Length of SH varied widely in our study. The lower level was $6 \mathrm{~mm}$ which was close to the report by Ukoha et $\mathrm{al}^{24}(6.1 \mathrm{~mm})$. But the upper level in our study was much higher compared to that of the Ukoha et $\mathrm{al}^{24}$ report ( $80 \mathrm{~mm}$ and $57 \mathrm{~mm}$, respectively). The arithmetic mean was $22.67 \mathrm{~mm}$, which was higher compared to the Ukoha et $\mathrm{al}^{24}(20 \mathrm{~mm})$, and lower compared to the Desai et $\mathrm{al}^{26}(25.2 \mathrm{~mm})$ reports. A longer hiatus facilitates needle entry into the sacral canal; at the same time, it indicates reduced distance between the apex of the $\mathrm{SH}$ and termination of the dural sac, thus increasing the possibility of the needle puncturing the dural sac. A shorter hiatus, especially in obese individuals because of the overlying fat, may prove difficult when locating the SH. In our study, $45.9 \%$ had a length of the $\mathrm{SH}$ in the range 11-20 mm, similar to the study conducted by Clarista et $\mathrm{al}^{10}(45 \%)$ and higher compared to the report by Desai et $\mathrm{al}^{26}(15 \%)$. A length of $\mathrm{SH}$ below $10 \mathrm{~mm}$ was found in $4.9 \%$, which is close to the report by Desai et $\mathrm{al}^{26}$ (4\%) but lower when compared to the report by Clarista et $\mathrm{al}^{10}(11.9 \%)$. A length of $\mathrm{SH}$ in the range $31-40 \mathrm{~mm}$ was found in $13.1 \%$, similar to the study conducted by Ukoha et $\mathrm{al}^{24}(13 \%)$.

Transverse width (intercornual distance) measurement has been found to range from $9 \mathrm{~mm}$ to $21 \mathrm{~mm}$, with mean $13.14 \mathrm{~mm} \pm 2.84 \mathrm{~mm}$. The range was narrower when compared with the report by Desai et $\mathrm{al}^{26}$ (3-25 mm, mean $19.5 \mathrm{~mm})$, Clarista et $\mathrm{al}^{10}(6.5-29.2 \mathrm{~mm}$, mean $16.87 \pm 3.66 \mathrm{~mm})$ and Ukoha et $\mathrm{al}^{24}(5-20.5 \mathrm{~mm}$, mean $12.35 \pm 3.12 \mathrm{~mm})$. Intercornual distance wider than a centimeter is sufficient for needle insertion. In our study intercornual distance up to $10 \mathrm{~mm}$ accounted for $19.7 \%$, which was higher compared to reports by Ukoha et $\mathrm{al}^{24}$ $(11.1 \%)$ and Clarista et $\mathrm{al}^{10}(2.1 \%)$. 
Table 4 Length, Transverse Width and AP Depth of Sacral Hiatus

\begin{tabular}{|c|c|c|c|c|c|c|}
\hline \multirow[b]{2}{*}{ Sr, No. } & \multicolumn{2}{|c|}{$\begin{array}{l}\text { Length of SH from Apex to Midpoint of } \\
\text { Base }\end{array}$} & \multicolumn{2}{|c|}{ Transverse Width of SH at the Base } & \multicolumn{2}{|c|}{ AP Diameter of SH at the Apex } \\
\hline & Length (mm) & $N$ (Percent) & Width (mm) & $N$ (Percent) & Diameter $(\mathrm{mm})$ & $N$ (Percent) \\
\hline I & $0-10$ & $3(4.9)$ & $6-10$ & $12(19.7)$ & $0-3$ & $5(8.2)$ \\
\hline 2 & $10.1-20$ & $28(45.9)$ & $10.1-15$ & $39(63.9)$ & $3.1-6$ & $37(60.7)$ \\
\hline 3 & $20.1-30$ & $21(34.4)$ & $15.1-20$ & $9(14.8)$ & $6.1-9$ & $19(31.1)$ \\
\hline 4 & $30.1-40$ & $8(13.1)$ & $\geq 20.1$ & I (I.6) & Total & 61 \\
\hline \multirow[t]{2}{*}{5} & $\geq 40.1$ & $\mathrm{I}(\mathrm{I} .6)$ & Total & $61(100)$ & & \\
\hline & Total & $61(100)$ & & & & \\
\hline
\end{tabular}

Table 5 Length, Transverse Width and AP Depth of Sacral Hiatus (Expressed in Terms of Mean, Standard Deviation and Range)

\begin{tabular}{|l|l|l|}
\hline Variables (in mm) & Mean士SD & Range \\
\hline Length & $22.67 \pm 11.84$ & $6-80$ \\
Transverse width & $13.14 \pm 2.85$ & $9-21$ \\
AP diameter & $5.57 \pm 1.53$ & $3-9$ \\
\hline
\end{tabular}

Anteroposterior diameter of the SH at apex needs to be sufficient to admit the needle into the sacral canal. In our study it ranged from 3 to $9 \mathrm{~mm}$, with mean 5.57 $\pm 1.53 \mathrm{~mm}$. Ukoha et $\mathrm{al}^{24}$ reported $0.4-11.1 \mathrm{~mm}$, with mean $5.52 \pm 1.89 \mathrm{~mm}$. Another report by Clarista et $\mathrm{al}^{10}$ found the range 1.98-9.92 mm, with mean $5.58 \pm$ $1.66 \mathrm{~mm}$. Clarista et $\mathrm{al}^{10}$ reported that the diameter of the $\mathrm{SH}$ at apex was less than $2 \mathrm{~mm}$ in $1 \%$ of sacral bones, hence impeding the use of $22 \mathrm{G}$ needles for CEB. In our study no case was reported below $2 \mathrm{~mm}$ anteroposterior diameter.

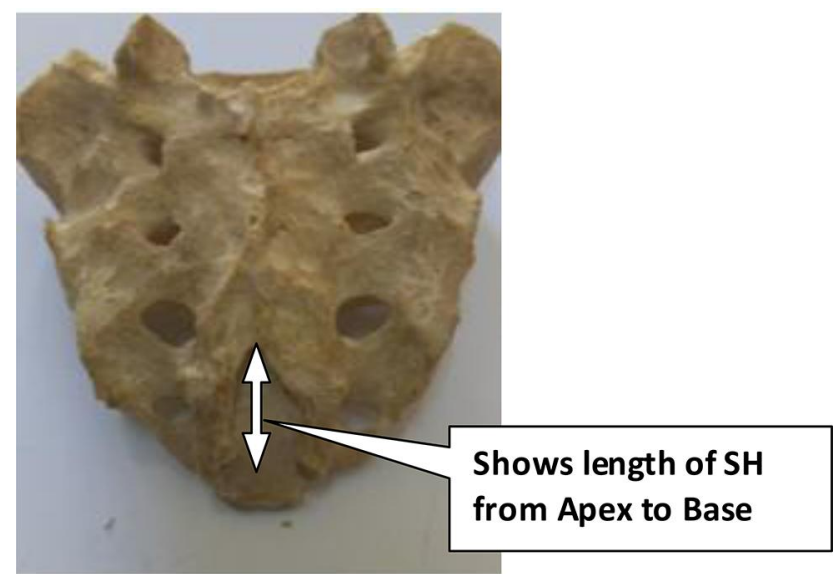

Figure II Schematic representation length of $\mathrm{SH}$ from apex to base.

\section{Conclusion}

The sacral hiatus has anatomical variations, and understanding of these variations may improve the success rate for administration of caudal epidural anesthesia. In this study, shapes of sacral hiatus that may present hindrance to needle insertion, higher level of apex of $\mathrm{SH}$ close to the dura and narrow transverse width of $\mathrm{SH}$ were found in significant percentage. This should be kept in mind while giving caudal anesthesia in the Ethiopian population.

\section{Abbreviations}

$\mathrm{AP}$, anteroposterior; $\mathrm{SH}$, sacral hiatus; $\mathrm{Co}$, coccyx; S, sacral; $\mathrm{CEB}$, caudal epidural block; CEA, caudal epidural anesthesia.

\section{Data Sharing Statement}

The data sets used and/or analyzed during the current study are available from the corresponding author on reasonable request.

\section{Ethics Approval and Consent to Participate}

Not applicable.

\section{Consent for Publication}

Not applicable.

\section{Acknowledgments}

Authors sincerely acknowledge University of Gondar for funding the research.

\section{Author Contributions}

All authors made a significant contribution to the work reported, whether that is in the conception, study design, execution, acquisition of data, analysis and interpretation, or in all these areas; took part in drafting, revising 
or critically reviewing the article; gave final approval of the version to be published; have agreed on the journal to which the article has been submitted; and agree to be accountable for all aspects of the work.

\section{Funding}

Funding was covered by University of Gondar (www.edu. uog.et).

\section{Disclosure}

The authors declare that they have no conflicts of interest for this work.

\section{References}

1. Patel ZK, Thummar B, Patel S, Zalawadia A. Multicentric morphometric study of dry human sacrum of Indian population in Gujarat Region. NJIRM. 2011;2(2):2-6.

2. Aggarwal A, Harjeet SD. Morphometry of sacral hiatus and its clinical relevance in caudal epidural block. Surg Radiol Anat. 2009;31(10):793-800. doi:10.1007/s00276-009-0529-4

3. Saha D, Bhattacharya S, Uzzaman A, Mazumdar S, Mazumdar A. Morphometric study of variations of sacral hiatus among West Bengal population and clinical implications. Ital J Anat Embryol. 2016;165-171.

4. Shewale SN, Laeeque M, Kulkarni PR, Diwan CV, Government H, College M. Morphological and morphometrical study of sacral hiatus. Int J Recent Trends Sci Tech. 2013;6(1):48-52.

5. The sacrum the holy bone; 2003. Available from: http://www. MedicineNet.com. Accessed June 15, 2013.

6. Frazer EJ. Anatomy of the Human Skeleton. London: J and A Churchill ltd; 1914:37-42.

7. Brailsford JF. Deformities of lumbosacral region of spine. Br J Surg. 1929;16(64):562-570. doi:10.1002/bjs.1800166405

8. Basaloglu H, Turgut M, Taser FA, Ceylan T, Basaloglu HK, Ceylan AA. Morphometry of the sacrum for clinical use. Surg Radiol Anat. 2005;27(6):467-471. doi:10.1007/s00276-005-0036-1

9. Ergur J, Akcalio O, Kiray A, Kosay C, Tayefi H. Neurovascular risk of sacral screws with bicortical purchase: an anatomical study. Eur Spine J. 2007;16(9):1529. doi:10.1007/s00586-007-0326-x

10. Clarista MQ, Gautham K. Morphometrical study of sacral hiatus in dry human. CIBTech J Surg. 2013;2(2):56-63.

11. Williams. PL, Bannister LH, Berry. MM, et al. Gray's Anatomy. 39th ed. Edinburgh: Elsevier Ltd; 2006:749-751.

Local and Regional Anesthesia

\section{Publish your work in this journal}

Local and Regional Anesthesia is an international, peer-reviewed, open access journal publishing on the development, pharmacology, delivery and targeting and clinical use of local and regional anesthetics and analgesics. The journal welcomes submitted papers covering original research, basic science, clinical studies, reviews \&
12. McLeod G. Spinal anaesthesia: intradural and extradural. In: Davis NJH, Cashman JN, editors. Lee's Synopsis of Anaesthesia. 13th ed. Churchill Livingstone, London: Elsevier; 2006:471-536.

13. Parashuram R. Morphometrical study of sacral hiatus in dry human sacra. J Res Med Sci. 2015;3(7):1726-1733. doi:10.18203/23206012.ijrms 20150260

14. Sekiguchi M, Yakuki S, Kikuchi S. An anatomic study of sacral hiatus: a basis for successful caudal epidural block. Clin J Pain. 2004;20(1):51-54. doi:10.1097/00002508-200401000-00010

15. Mrudula C, Naveena S. Morphometry of sacral hiatus and its clinical relevance. Int $J$ Adv Res. 2013;1(7):29-34.

16. Mohamed SM, Omayma MM, El Raouf HHA, Hosam MA. Morphometric study Of Sacral hiatus in adult human Egyptian sacra: their significance in caudal epidural anesthesia. Saudi $J$ Anaesth. 2012;6(4):350-357. doi:10.4103/1658-354X.105862

17. Edwards WB, Hingson RA. Continuous caudal anaesthesia in obstetrics. Am J Surg. 1942;57(3):459-464. doi:10.1016/S00029610(42)90599-3

18. Anjali A, Aditya A, Daisy S. Morphometry of sacral hiatus and its clinical relevance in caudal epidural block. Surg Radiol Anat. 2009;31:793800.

19. Chen PC, Tang STF, Hsu T-C, et al. Ultrasound guidance in caudal epidural need placement. Anaesthesiol. 2004;101(1):181-184. doi:10.1097/00000542-200407000-00028

20. Senoglu N, Senoglu M, Oksuz H, et al. Landmarks of the sacral hiatus for caudal epidural block: an anatomical study. Br J Anaesth. 2005;95(5):692-695. doi:10.1093/bja/aei236

21. Nagar SK. A study on sacral hiatus in dry human sacra. $J$ Anat Soc India. 2004;53:18-21.

22. Suma HY, Kulkarni R, Kulkarni RN. A study of sacral hiatus among sacra in South Indian population. Anat Karnataka. 2011;5:40-44.

23. Phalgunan V, Baskaran S. Morphometric analysis of sacral hiatus and its Clinical Significance. Health Agenda. 2013;1:10-15.

24. Ukoha UU, Okafor JI, Anyabolu AE, Ndukwe GU, Eteudo AN, Okwudiba NJ. Morphometric study of the sacral hiatus in Nigerian dry human sacral bones. Int J Med Res Heal Sci. 2014;3(1):115.

25. Bhattacharya S, Majumdar S, Chakraborty $\mathrm{P}$, Mazumdar S, Mazumdar A. Original article: a morphometric study of sacral hiatus for caudal epidural block among the population of West Bengal. Int J Basic Appl Med Res. 2013;Vol.-2(Issue-7):660-667.

26. Desai RR, Jadhav SD, Doshi MA, Ambali MP, Desai AR. Variations in anatomical features of the sacral hiatus in Indian dry sacra. Int J Med Res Heal Sci. 2014;3(3):634.

27. Malarvani T, Ganesh E, Nirmala P. Study of sacral hiatus in dry human sacra in Nepal, Parsa Region. Int J Anat Res. 2015;3 (1):848-855. doi:10.16965/ijar.2014.527 evaluations, guidelines, expert opinion and commentary, case reports and extended reports. The manuscript management system is completely online and includes a very quick and fair peer-review system, which is all easy to use. Visit http://www.dovepress.com/testimonials. php to read real quotes from published authors. 